\title{
MAKALAH
}

Serangan Hoax dan Provokasi ke Berbagai Aspek Kehidupan Disorot dalam Sudut Kemoralan

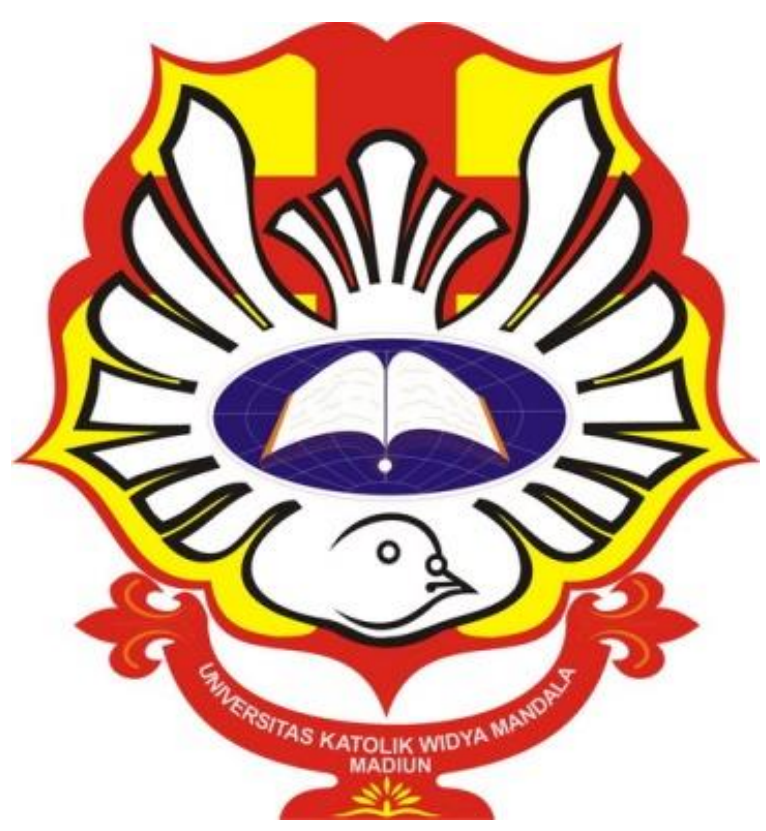

Disusun oleh:

$$
\begin{array}{ll}
\text { Nama } & : \text { Serlyna Mutiara Dewi } \\
\text { NIM } & : 32318016
\end{array}
$$

PROGRAM STUDI D-III FARMASI

FAKULTAS MATEMATIKA DAN ILMU PENGETAHUAN ALAM

UNIVERSITAS KATOLIK WIDYA MANDALA MADIUN 


\begin{abstract}
ABSTRAK
Berita hoax makin kesini makin menjadi-jadi, apalagi jika ditambahi "bumbu-bumbu" oleh para pelaku provokasi. Ratusan ribu situs penyebar hoax atau yang sering disebut "berita palsu" ini sudah merajalela di kehidupan bermasyarakat. Ditambah lagi para influencer yang membuat kontroversi demi menaikkan rating nya. Tidak hanya itu, bahkan jurnalis yang mempunyai kode etik profesi pun kerap kali membuat artikel dengan judul yang "ambigu" sehingga menimbulkan presepsi ganda bagi masyarakat, dan menimbulkan konflik prokontra. Berita hoax tak hanya menyentuh bidang hiburan, bahkan politik dan sosial pun tak kalah dari pandangan provokator. Namun semua itu berujung kembali lagi ke pembaca, apakah ia mau menelan mentah-mentah atau di filter terlebih dahulu.
\end{abstract}




\section{Serangan Hoax dan Provokasi ke Berbagai Aspek Kehidupan Disorot dalam Sudut Kemoralan}

Hoax merupakan sebutan bagi sebuah berita, ucapan, maupun kalimat yang tidak bisa atau belum dibuktikan kebenarannya melalui data-data yang riil. Biasanya, hoax digunakan untuk menimbulkan konflik pro-kontra, memprovokasi masyarakat, menebar kebencian, menjatuhkan pihak lain, yang pada akhirnya memecah-belah masyarakat. Menanggapi hal ini, masyarakat diharapkan mampu berpikir kritis dan mem-filter dan selektif terhadap segala informasi yang diterimanya dengan baik. Hoax yang sering muncul adalah berupa "gosip" yang hanya dari mulut ke mulut, tanpa data riil dan bukti, yang berasal dari sembarang asumsi masyarakat, ditambah dengan keadaan yang kondusif mendukung hoax ini semakin menjadi-jadi.

Banyak bidang yang telah dikontaminasi oleh adanya berita hoax. Baik dari sudut hiburan, politik, sosial, pemerintah, kesehatan dan masih banyak lagi. Bila Ir. Soekarno melihat keadaan Indonesia saat ini, beliau pasti sudah kecewa bercampur sedih. Perjuangan di masanya lebih mudah, karena beliau tinggal menyatukan pikiran para pejuang untuk menuju ke kemerdekaan, karena pada saat itu bangsa Indonesia merasakan keadaan yang sama, dan memiliki keinginan yang kurang lebih sama. Dibandingkan dengan masa kini, bangsa Indonesia yang harus melawan sesama warga negaranya sendiri demi kesejahteraan bersama dan lebih sulit, karena ada lebih dari 264 juta penduduk Indonesia yang memiliki keadaan, pemikiran, prinsip, dan tujuan yang berbeda-beda, serta dengan cara menghadapi masalah kehidupan yang berbeda-beda pula.

Hiburan di tanah air Indonesia sudah tidak bisa dihitung dengan jarijemari lagi berapa jumlah berita hoax yang ditebarkan selama satu tahun terakhir ini. Salah satu contohnya yaitu pada kasus Young Lex yang membuat geger dengan bekas luka babak belur di wajahnya yang ternyata hanyalah hasil make-up belaka. 
Tak hanya di bidang hiburan, bahkan bidang politik pun juga ikut-ikutan. Negara bukanlah mainan boneka yang bisa diatur dan dimainkan seenaknya, sulit untuk menyatukan pikiran ratusan juta umat, dan bersama-sama memperjuangkan kesejahteraan umum. Kerja sama disini sangat diperlukan. Bila kepercayaan sulit untuk dijaga bahkan di dunia politik, bagaimana masyarakat bisa mempercayai pembangunan dan pemerataan negara?

Menanggapi dari pelajaran tentang Filsafat Moral atau biasa disebut dengan Etika, hoax disini sudah jelas menyalahi kodrat moralitas. Mengapa? Begini, moralitas hanya bisa diterapkan kepada manusia, karena hanya manusia lah yang diciptakan memiliki akal budi di dunia ini, bukan hewan maupun tumbuhan, apalagi benda mati. Tidak bisa kita menyalahkan internet maupun teknologi yang membuat semua pekerjaan menjadi mudah, semua informasi dapat menyebar dengan cepat. Karena jika kita kupas lagi, pada dasarnya semua teknologi tersebut berasal dari buatan manusia, semua kemajuan di dunia ini berujung kepada buatan manusia lagi. Artinya semua yang terjadi di dunia ini adalah hasil dari buatan manusia itu sendiri. Karena "otak" dari teknologi itu sendiri merupakan hasil karya dari "otak" manusia itu sendiri. Lalu bagaimana kita bisa menilai moralitas seseorang, jika moral itu sendiri berasal dari pikiran manusia? Tindakan manusia adalah perwujudan konkret dari pemikiran manusia.

Hoax dapat menyakiti korban hoax itu sendiri, dan tentu saja itu merusak tatanan nilai untuk saling menghargai dan menghormati sesama. Bagaimana dengan provokator? Provokator tentu tidak menyebabkan kejadian yang baik, karena justru mengakibatkan adanya perselisihan, kerusuhan, bahkan peperangan. Dipandang dari sudut moralitas, tentu penyebar hoax dan provokator tidak bisa dianggap sebagai suatu tindakan yang baik secara moral, karena ia tidak menghasilkan suatu keadaan yang baik pula.

Suatu tindakan dapat disorot moralitasnya apabila tindakan tersebut dilakukan dengan tahu-mau-bebas. Tindakan menyebar hoax dan provokasi tersebut apakah diketahui oleh si pelaku? Misalnya, pelaku penyebar hoax jelas- 
jelas tahu bahwa informasi yang akan dia sebarkan itu salah, tapi apakah ia memilih untuk tetap membeberkan atau menyebarkan informasi tersebut atau tidak. Kemudian kalau-kalau pelaku sudah mengetahui dan memaui (dilakukan dengan sengaja) untuk menyebarkan informasi itu, jelas-jelas dia bersalah secara moral, apalagi dengan keadaan tidak terpaksa.

Hoax dan provokasi masuk ke dalam ranah directly voluntary (tindakan yang dikehendaki dan secara langsung menginginkannya), karena pelaku jelas menghendaki tindakan itu dan menghendaki dampak yang pelaku sendiri sudah mengetahuinya. Karena tindakannya itu merupakan kehendaknya sendiri, maka semua tanggungjawab atas perbuatannya mutlak dalam kuasa pelaku, tidak bisa dilimpahkan.

Hati nurani dari pelaku hoax dan provokasi itu dapat dikatakan sesat, karena ia tahu bahwa tindakannya itu buruk, tapi ia tidak mau tahu dan tetap melakukannya, alias ngeyel. Tetapi bisa juga dikatakan tumpul, apabila dibalik tindakannya itu ada tujuan tertentu yang ingin dicapai yang tidak berhubungan secara tidak langsung dari perbuatannya, seperti adanya pihak yang akan memberinya upah berupa material. Demi mendapat upah material tersebut pelaku mau melakukan tindakan dan tidak memikirkan atau bahkan tidak mau tahu dan tidak peduli akan dampaknya. Atau dengan kata lain pelaku telah dibutakan oleh material tersebut (materialisme).

Apabila seseorang menerima informasi dan belum mengetahui kebenaran informasi tersebut secara lengkap dan belum terbukti kebenarannya, dikatakan orang tersebut bersalah apabila langsung menyebarkan informasi tersebut tanpa mencari tahu terlebih dahulu. Dari sini diharapkan semua orang memiliki selektif terhadap arus informasi yang cepat dan tidak $100 \%$ dapat dibuktikan kebenarannya.

Mengutip dari buku Filsafat Moral yang ditulis Dr. Agustinus W. Dewantara, S.S., M.Hum, terdapat prinsip-prinsip refleksif dari hati nurani yang 
benar, yang bisa dikaitkan dengan masalah serangan hoax dan provokasi ini, yaitu:

1. Recta rasio: menggunakan akal budi secara sehat dan jernih, bertindak sesuai dengan akal budi, dengan tidak perasaan atau emosi. Dikaitkan dengan masalah ini, tidak bisa asal menyebarkan informasi hanya karena hal itu berhubungan dengan seseorang atau hal yang tidak disukai secara personal. Jika dipikir dengan akal budi yang sehat, urusan personal tidak bisa dijadikan pacuan untuk membuat seseorang bermasalah dengan publik.

2. Kaidah kencana atau hukum timbal balik atau hukum tabur tuai. Jika tidak mau dibuat tercemar nama baiknya, ya jangan mencemarkan nama baik orang lain. Jika mau dihormati, ya hormatilah orang lain.

3. Occasion proxima peccati evitanda: hindari kesempatan yang paling dekat dengan dosa. Kalau lemah saat diiming-imingi jaminan uang, ya jangan mendekati orang yang suka melempar batu sembunyi tangan, menggunakan anak buah untuk melakukan tindakan kejahatan dengan imbalan uang.

4. Prinsip teologis: tujuan tindakan harus selalu masuk akal, benar dan terarah kepada kebaikan meski menghadapi resiko yang sulit. Misalnya, mendapat tawaran untuk memprovokasi dengan jaminan biaya hidup akan ditanggung oleh pemberi tawaran, pada saat itu sedang mengalami krisis moneter. Tindakan yang paling baik dilakukan adalah menolaknya, meskipun resikonya akan membuang kesempatan untuk hidup enak dan terjamin padahal kondisi saat itu sedang krisis. Jika memang ingin lepas dari krisis, ya bekerjalah dengan lebih giat, lakukan inovasi dan pengembangan terhadap segala usaha.

5. In dubio via tutior eligenda est: pilih jalan yang lebih aman jika ada dalam keraguan. Jika masih ragu-ragu dalam bertindak, jangan nekat, jangan dilakukan dulu. Cari tahu seluk-beluknya dengan lengkap, jika baik baru lakukanlah, kalau tidak baik ya hindarilah. Tidak dibenarkan menyebarkan informasi yang belum tentu kebenarannya, apalagi yang masih "katanya". 
6. Epikeia: bertanggung jawab atas tindakannya meskipun tidak ada hukum. Meskipun tidak ada aturan yang tidak memperbolehkan memprovokasi, manusia tetap wajib mempertanggungjawabkan tindakannya.

Tidak jarang ditemukan adanya tindakan provokasi yang berhubungan dengan agama. Kita tinggal di Indonesia, negara multicultural yang penduduknya tidak beragama sama, tidak memiliki kepercayaan yang sama. Nyatanya hukum agama dapat ditafsirkan dari berbagai macam sudut pandang. Seringkali karena berhubungan dengan agama, manusia menjadi overthinking atau berlebihan dalam menanggapi sesuatu dan selalu dihubungkan dengan agama. Padahal pada intinya, Sang Pencipta hanya menginginkan manusia hidup bersama dengan rukun.

Tindakan manusia selalu memiliki nilai, yaitu nilai baik dan nilai buruk. Ketika manusia yang selama ini terus membeberkan informasi hoax atau kerap kali berbohong maka ia akan dicap sebagai pembohong oleh orang-orang disekitarnya. Bila di kemudian hari ia membeberkan informasi yang dapat dibuktikan kebenarannya, bagaimana orang lain bisa percaya? Hal ini justru bisa merugikan manusia itu sendiri. Tidak bisa ia menuntut orang lain harus percaya kepadanya, karena kepercayaan orang lain kepadanya sudah ia rusak sedari dulu dank arena sudah terlalu sering akhirnya kepercayaan orang lain kepadanya itu sudah tidak bisa dibangun kembali. Akibatnya orang itu sendiri yang mengalami keresahan dan kesulitan dalam hidupnya. Karena ia sendiri tidak dapat dipercaya orang lain. Contoh yang ekstrim, misalnya tidak diterima bekerja karena atasan takut orang tersebut akan korupsi, saat berbelanja uang yang ia berikan akan diragukan oleh penjual karena takut itu adalah uang palsu atau bahkan dianggap hasil korupsi.

Dalam kasus hoax dan provokasi ini, beberapa nilai-nilai moral yang mengalami kemerosotan yaitu, kebenaran, kemanusiaan, keadilan, kejujuran, toleransi, cinta akan kedamaian, kepedulian, dst.

Dalam menjalani hidup, subjek menjadi penanggung jawab mutlak terhadap semua tindakannya. Tanggung jawab yang dimaksudkan disini adalah 
menuju kesempurnaan hidup dengan berelasi dengan baik dengan orang lain, dengan kata lain dengan saling mengisi ketidaksempurnaan antar sesama. Saling mengisi ketidaksempurnaan, bukan saling menyakiti, memanfaatkan, bahkan saling menghancurkan. Penebaran hoax sendiri merupakan tindakan yang menyakiti orang lain, menghancurkan orang lain, mencemarkan nama baik orang lain, menimbulkan salah presepsi seseorang terhadap korban hoax. Tidak berbeda dengan provokasi, tindakan tersebut merupakan tindakan yang mencemarkan nama baik dan bahkan bisa menghancurkan orang lain. Biasanya provokasi dilakukan atas dasar kebencian dan rasa dendam terhadap seseorang, dan menginginkan orang lain juga memiliki kebencian kepada orang tersebut tidak peduli bagaimanapun caranya asal orang yang dibenci provokator menjadi lebih dimusuhi oleh orang lain, apapun alasannya.

Hoax dan provokasi memiliki dampak yang kurang lebih sama, yaitu dapat menyebabkan adanya salah paham, pencemaran nama baik, atau bahkan yang lebih ekstrim lagi yaitu menimbulkan kebencian dan rasa dendam. Pencegahan serangan hoax dan provokasi yaitu menyaring segala informasi yang masuk (bersikap selektif), mencari data terlebih dahulu dari segala penelitian serta bukti yang membenarkan informasi tersebut. 


\section{DAFTAR PUSTAKA}

Dewantara, A. (2017). Filsafat Moral (Pergumulan Etis Keseharian Hidup Manusia).

Dewantara, A. (2018). Pancasila Dan Multikulturalisme Indonesia. 